\section{cambridge.org/pao}

\section{Research Article}

Cite this article: Gonçalves LR, Teixeira MMG, Rodrigues AC, Mendes NS, Matos CA, Pereira CL, Machado RZ, André MR (2018). Molecular detection of Bartonella species and haemoplasmas in wild African buffalo (Syncerus caffer) in Mozambique, Africa. Parasitology Open 4, e15, 1-8. https://doi.org/ 10.1017/pao.2018.10

Received: 20 November 2017

Revised: 26 April 2018

Accepted: 30 April 2018

\section{Key words:}

African buffalo; Bartonella; haemoplasmas; phylogenetic assessment; Syncerus caffer

\section{Author for correspondence:}

Marcos Rogério André, E-mail: marcos_andre@ fcav.unesp.br (c) Cambridge University Press 2018. This is an Open Access article, distributed under the terms of the Creative Commons AttributionNonCommercial-ShareAlike licence (http:// creativecommons.org/licenses/by-nc-sa/4.0/), which permits non-commercial re-use, distribution, and reproduction in any medium, provided the same Creative Commons licence is included and the original work is properly cited. The written permission of Cambridge University Press must be obtained for commercial re-use.

\section{CAMBRIDGE} UNIVERSITY PRESS

\title{
Molecular detection of Bartonella species and haemoplasmas in wild African buffalo (Syncerus caffer) in Mozambique, Africa
}

\section{Luiz Ricardo Gonçalves ${ }^{1}$, Marta Maria Geraldes Teixeira², Adriana Carlos Rodrigues ${ }^{2}$, Natalia Serra Mendes ${ }^{1}$, Carlos Antonio Matos ${ }^{1,3}$, Carlos Lopes Pereira ${ }^{4}$, Rosangela Zacarias Machado ${ }^{1}$ and Marcos Rogério André ${ }^{1}$}

${ }^{1}$ Department of Veterinary Pathology, School of Agrarian and Veterinary Sciences (FCAV/UNESP), Jaboticabal, São Paulo, Brazil; ${ }^{2}$ Institute of Biomedical Sciences, University of São Paulo (ICB/USP), São Paulo, Brazil; ${ }^{3}$ Direction of Animal Science, Maputo, Mozambique and ${ }^{4}$ Wildlife Conservation Society, Maputo, Mozambique

\begin{abstract}
The African buffalo (Syncerus caffer), a mammal species whose population is declining, can play a role as a reservoir or carrier of a wide number of arthropod-borne pathogens. Translocation procedures have been used as an alternative approach for species conservation. However, the veterinary aspects of this sort of procedures are extremely important to minimize the impact on animal health. In order to detect Bartonella and haemoplasmas, two important group of bacterial that have an impact in both human and animal health, EDTA whole-blood samples were screened for the presence of these bacterial pathogens by molecular techniques. As a result, a molecular occurrence of 4.1 and $15.4 \%$ for Bartonella spp. and haemoplasmas, respectively, was reported among 97 wild buffaloes sampled during a translocation procedure from Marromeu to Gorongosa Reserve, Mozambique. Additionally, phylogenetic analyses of the obtained sequences were conducted. At least, three bovineassociated pathogens, namely B. bovis, $M$. wenyonii and 'Candidatus M. haemobos', as well as a probably new Bartonella genotype/species were detected in S. caffer. Further studies are needed in order to determine whether these bacterial species may cause impact in buffaloes and other sympatric ruminant species living in the release site.
\end{abstract}

\section{Introduction}

The African buffalo (Syncerus caffer) plays a role as a reservoir or carrier of a wide number of arthropod-borne pathogens, such as Theileria, Ehrlichia, Babesia and Anaplasma species (Andrew and Norval, 1989; Allsopp et al., 1999; Eygelaar et al., 2015; Machado et al., 2016). Moreover, buffaloes are known to harbour other economically important infectious pathogens, such as Mycobacterium tuberculosis, foot-and-mouth disease virus and Brucella abortus (Godfroid, 2002; Michel et al., 2006; Van Schalkwyk et al., 2016). Although widely distributed throughout sub-Saharan Africa, the African buffaloes are currently confined to protected areas. The species distribution and numbers have been strongly reduced by habitat loss and hunting (IUCN - Downloaded on 29 July 2016).

Many native and exotic animal species have been selected for translocations procedures around the world (Seddon et al., 2014; Soorae, 2016). The translocation is defined as the human-mediated movement of living organisms from one area to another (Woodford and Rossiter, 1993). Although the translocation of endangered species has become an important conservation approach, the project success depends to a large extent on the care with which wildlife biologists and veterinarians evaluate the suitability of the chosen release site (Woodford and Rossiter, 1993). Adequate managements are extremely important for the translocation procedures since the introduction of pathogens into naive resident wildlife community or the translocation of animals from free-vectors and pathogens sites to enzootic areas can be catastrophic.

In this context, Bartonella species and haemotropic mycoplasmas (also known as haemoplasmas) emerge as important arthropod-borne pathogens that have an impact in humans and animals' health (Maggi et al., 2013a; Breitschwerdt, 2014).

The Bartonella genus comprises a successful group of Gram-negative bacteria parasites (Birtles, 2005), which infects mainly erythrocytes and endothelial cells from a wide range of animal species, including humans (Breitschwerdt et al., 2010; Harms and Dehio, 2012). This success is characterized by the high prevalence of the infection and diversity of host species (Birtles, 2005; Kosoy et al., 2012). Currently, five (B. bovis, B. chomelii, B. schoenbuchensis, B. capreoli and B. melophagi) out of the 36 named Bartonella species/subspecies described have been associated with ruminants (Buffet et al., 2013; Breitschwerdt, 2017).

Contrariwise, haemoplasmas are cell wall-less uncultivated epicellular bacteria that attach to red blood cells surface of a wide range of animals, including humans (Neimark et al., 2001; Maggi et al., 2013b). Among the haemoplasmas, Mycoplasma ovis, Mycoplasma wenyonii and 'Candidatus Mycoplasma haemobos' have been recognized as pathogens of domestic 
Fig. 1. Map of Mozambique country highlighting the districts where the buffalo were translocated.

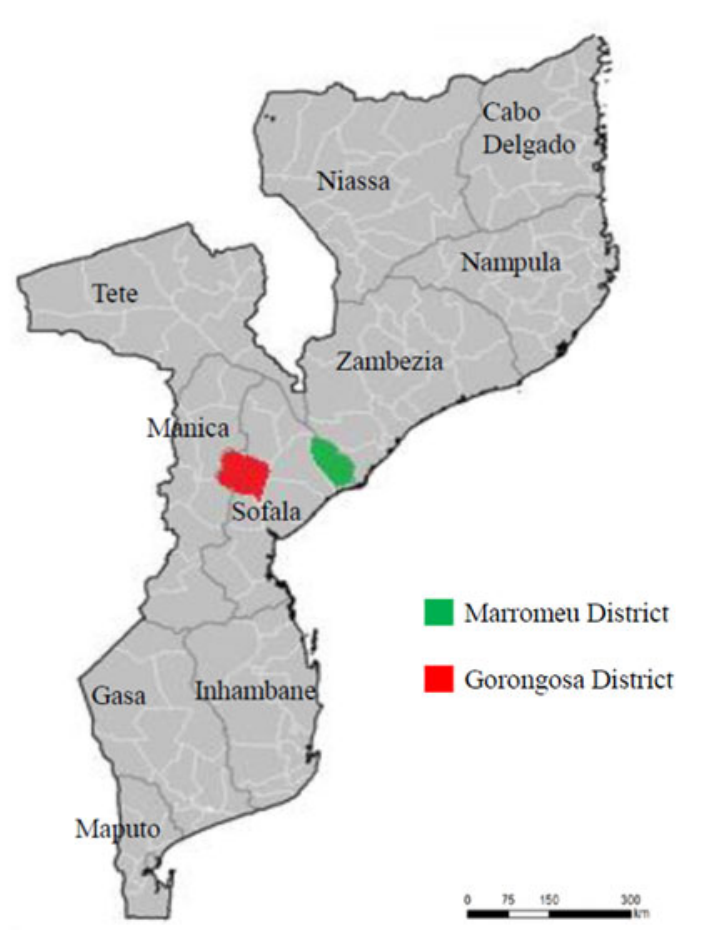

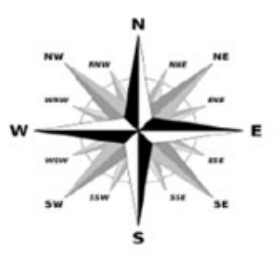

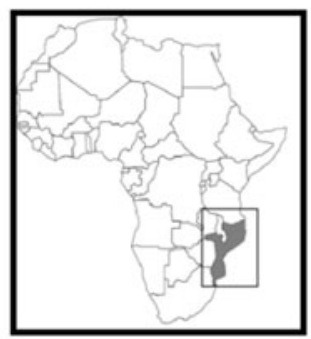

ruminants worldwide. In addition, an expanding number of Candidatus to new Bartonella and Mycoplasma species/genotypes have globally been reported in ruminants (Stoffregen et al., 2006; Watanabe et al., 2010; Sato et al., 2012; Maggi et al., 2013b; Dahmani et al., 2017).

Although the impact of bartonellae and haemoplasmas in livestock is still unknown, the gaps in the biology of these bacteria warrant further investigation. Indeed, there are limited data on the occurrence, distribution, genetic diversity, pathogenicity and transmission of arthropod-borne agents among wild ruminants.

The elucidation of these bacterial cycles in nature, including the identification of hosts, vectors and the species distribution in a particular ecotope shows great importance (Gutiérrez et al., 2014). Additionally, the African buffalo plays a role as reservoirs for vector-borne pathogens and may represent a serious threat to the livestock industry (Andrew and Norval, 1989; Allsopp et al., 1999; Eygelaar et al., 2015; Van Schalkwyk et al., 2016).

Therefore, the present study aimed to investigate the occurrence of Bartonella and haemoplasmas infection in wild buffaloes (S. caffer) submitted to translocation in Sofala province, Mozambique, Africa.

\section{Material and methods}

\section{Blood collection of African buffalo}

The present study was carried out when Carlos L. Pereira was the Director of Conservation Gorongosa National Park, Mozambique. Animal management and welfare during the fieldwork with Cape buffaloes were conducted in accordance with national legislation on the use of animals for research implemented by the National Administration for the Conservation Areas (ANAC) of Mozambique. In 2011, blood samples were collected from 97 wild African buffalo ( $S$. caffer) in Marromeu Reserve, Mozambique. This reserve is a special buffalo protection area located in the Marromeu district (Sofala Province) (Fig. 1), with an area of $1.500 \mathrm{~km}^{2}$ (http://www.jenmansafaris.com). Sampled animals were apparently healthy young male and female individuals. Approximately $10 \mathrm{~mL}$ of blood samples were collected of each animal before they were transferred from Marromeu Reserve (the site where there was contact with cattle) to the Gorongosa National Park (the site where there was no contact with cattle), distant around 300 kilometers from each other. The EDTA-blood were mixed (v/v) with ethanol, transported to the laboratory and posterior kept at $-20{ }^{\circ} \mathrm{C}$ until sent an aliquot ( $\sim 1 \mathrm{~mL})$ to Brazil (Machado et al., 2016; Rodrigues et al., 2017).

\section{Blood samples and DNA extraction}

EDTA-blood samples collected from buffaloes were mixed (v/v) with ethanol for further DNA extraction. In Brazil, the blood samples from these buffaloes were incubated in a lysis buffer (1\% SDS, $100 \mathrm{~mm}$ EDTA at $\mathrm{pH} 8.0,20 \mathrm{~mm}$ Tris- $\mathrm{HCl}$ at $\mathrm{pH} 8.0$ and $350 \mathrm{mg} \mathrm{mL}{ }^{-1}$ of proteinase $\mathrm{K}$ ) at $37^{\circ} \mathrm{C}$ for $18 \mathrm{~h}$ and centrifuged at $14.000 \mathrm{~g}$ for $5 \mathrm{~min}$. The DNA was purified using Wizard Purification Systems (Promega). The concentration of each DNA sample was determined in a NanoDrop 2000c spectrophotometer (Thermo Scientific, San Jose, CA, USA) (Machado et al., 2016).

Molecular diagnosis of Bartonella and haemoplasmas species in African buffalo blood samples

A previously described broad range Taqman quantitative realtime PCR (qPCR) protocol based on $n u o G$ gene was used aiming to detect Bartonella species DNA as previously described (André et al., 2016). The qPCR amplifications were conducted in lowprofile multiplate unskirted PCR plates (BioRad, CA, USA) using a CFX96 Thermal Cycler (BioRad, CA, USA). Serial dilutions were performed aiming to construct standard curves with different concentrations of plasmid DNA (pIDTSMART Integrated DNA Technologies) $\left(2.0 \times 10^{7}-2.0 \times 10^{0}\right.$ copies $\left.\mu \mathrm{L}^{-1}\right)$ encoding an $83 \mathrm{bp}$ insert of nuoG Bartonella henselae (André et al., 2016). qPCR assays were performed including duplicates of each buffalo DNA sample. All the duplicates showing a difference in $\mathrm{Cq}$ values higher than 0.5 were retested. Amplification 
efficiency $(E)$ was calculated from the slope of the standard curve in each run using the following formula $\left(E=10^{-1 / \text { slope }}\right)$.

Additionally, two specific conventional PCR (cPCR) protocols based on 16S rRNA were used to amplify M. wenyonii ( $\sim 330 \mathrm{bp}$ ) and 'Candidatus M. haemobos' DNA (279 bp) as previously described (Nishizawa et al., 2010; Su et al., 2010). Bartonella (KX086714), 'Candidatus M. haemobos' (KY328834) and $M$. wenyonii (KY328836) DNA samples previously obtained from naturally infected rodents and buffaloes (Gonçalves et al., 2016; Santos et al., 2018), respectively, were used as positive controls. Ultra-pure sterile water and blood samples from calves previously tested negative for both pathogens were used as negative controls in all PCR assays described above. In order to prevent PCR contamination, DNA extraction, reaction setup, PCR amplification and electrophoresis were performed in separated rooms.

\section{Molecular characterization of Bartonella and haemoplasma species}

Samples from qPCR assays-positive buffalo were submitted to cPCR assays targeting four protein-coding genes with great potential to differentiation among related Bartonella species (La Scola et al., 2003; Kosoy et al., 2017), namely gltA (350 bp), rpoB (825 bp), ftsZ (515 bp) and groEL (752 bp) genes, as previously described (Norman et al., 1995; Birtles and Raoult, 1996; Renesto et al., 2001; Zeaiter et al., 2002; Paziewska et al., 2011). Bartonella DNA previously detected in rodents was used as positive control (Gonçalves et al., 2016). On the other hand, in order to better characterize the initial PCR assay results, haemoplasmapositive buffalo samples were additionally submitted to a CPCR assay targeting a $16 \mathrm{~S}$ rRNA larger fragment ( $~ 800 \mathrm{bp})$, as previously described (Maggi et al., 2013b). Mycoplasma haemofelis DNA previously detected in cats in Brazil was used as positive control (Santis et al., 2014).

All cPCR products were purified using Silica Bead DNA Gel Extraction Kit (Fermentas, SP, Brazil). Purified amplified DNA fragments were submitted to sequence confirmation in an automatic sequencer (ABI Prism 310 Genetic Analyser - Applied Byosystem/Perkin Elmer) in both directions using the same primers used for PCR detection. In order to correctly determine the nucleotide composition, the electropherograms were submitted to PhredPhrap analysis (Ewing et al., 1998). The Phred quality score (peaks around each base call) was established higher than 20 (99\% in the accuracy of the base call). Subsequently, the sequences were submitted to BLASTn and phylogenetic analyses.

\section{Phylogenetic analyses of gltA, ftsZ and 16S rDNA sequences}

The sequences obtained from gltA and ftsZ Bartonella and 16S rRNA haemoplasmas cPCR assays were identified by BLASTn, using the Megablast (highly similar sequences - using default parameters). Subsequently, obtained sequences were aligned with those retrieved from GenBank database using Clustal/W (Thompson et al., 1994), adjusted in Bioedit v. 7.0.5.3 (Hall, 1999), and submitted to phylogenetic analysis. The maximum likelihood (ML) phylogenetic analysis was inferred with RAxML-HPC BlackBox 7.6.3 (Stamatakis et al., 2008). Also, in order to perform a robust phylogenetic analysis among the protein-coding gene sequences, the Bartonella gltA and fts $Z$ nucleotide sequences were submitted to other two methods. Phylogenetic analysis based on Bayesian inference (BI) was done using MrBayes on XSEDE (v. 3.2.6) (the a posteriori probability values higher than $50 \%$ were accessed with $10^{6}$ replicates; the first $25 \%$ trees were discarded as burn-in). Finally, these sequences were analysed by neighbour-joining (NJ) using the MEGA5.05 software. The AIC (Akaike information criterion) available on MEGA 5.05 software was applied to identify the most appropriate model of nucleotide substitution.

\section{Results}

Occurrence and molecular characterization of Bartonella and haemoplasma species in African buffalo

Out of 97 African buffalo blood samples submitted to Bartonella-qPCR, four (4.1\%) were positive. The mean amplification efficiency was $E=90.7 \%$ [(ranging from 90.5 to $90.9 \%$ ); slope $\left.=-3.568 ; r^{2}=0.996\right]$. All blood samples showed low number of Bartonella-DNA copies $\mu \mathrm{L}^{-1} \quad \# 45=0.046 \times 10^{2}$; \#50= $0.041 \times 10^{2} ; \quad \# 62=0.037 \times 10^{2} ;$ and $\# 44=0.002 \times 10^{2}$ copies $\left.\mu \mathrm{L}^{-1}\right)$. Among the four blood samples positive to Bartonella in qPCR assay, only the sample \#62 showed to be positive in gltA and $f t s Z \mathrm{cPCR}$ assays. None blood samples showed positive results in cPCR assays targeting $r p o B$ and groEL genes. The glt $A$ nucleotide sequence amplified in the present study shared 99\% identity with B. bovis (KF199897) detected in cattle from Guatemala (Bai et al., 2013). On the other hand, the obtained fts $Z$ nucleotide sequence shared 98\% identity with Bartonella sp. (AB703117) previously detected in a Japanese Sika deer (Cervus nippon centralis) (Sato et al., 2012).

Additionally, $15.4 \%$ (15/97) samples were positive to haemoplasmas. Among them, 14.4\% (14/97) and 4.1\% (4/97) showed positive results to $M$. wenyonii, and 'Candidatus $M$. haemobos', respectively. Four (4.1\%) samples were simultaneously positive to $M$. wenyonii and 'Candidatus M. haemobos'. The two haemoplasmas amplicons sequenced shared 99 and 99\% identity with $M$. wenyonii (KX171205) and 'Candidatus M. haemobos' (EF616468) nucleotide sequences detected in cattle from Mexico and Switzerland, respectively. None sample was simultaneously positive to Bartonella and haemoplasmas. The $16 \mathrm{~S}$ rDNA sequences amplified in the present study showed query coverage ranging from 99 to $100 \%$. All nucleotide sequences submitted to BLASTn and phylogenetic analyses were deposited in GenBank under the following access numbers: Bartonella (MF774324-MF774325) and haemoplasmas (MF981847 and MF992084).

\section{Phylogenetic analysis}

The phylogenetic analyses performed among the protein-coding gene sequences ( $g l t A$ and $f t s Z$ ), using different methods (ML, $\mathrm{MI}$ and NJ) yielded congruent tree topologies (Figs 2, 3 and S1-S4). Additionally, according to BLASTn analysis, the Bartonella glt $A$ and $f t s Z$ sequences amplified from the same animal (\#62) showed a distinct phylogenetic positioning in ML, BI and NJ analyses (Figs 2, 3 and S1-S4). The gltA sequence (MF774324), which shared 99\% identity with B. bovis, clustered with other $B$. bovis sequences, including $B$. bovis sequences previously amplified in water buffalo from Thailand (Bai et al., 2013), showing high support index (ranging from 97 to 100\%) (Fig. 2 and S1, S2). On the other hand, although the ftsZ sequence (MF774325) clustered with other ruminant-associated Bartonella sequences, it was not closely related to any of these sequences, remaining in a separate branch in all different methods and supported by a high support index (ranging from 80 to 100\%) (Fig. 3 and S3, S4).

Also in agreement to BLASTn analysis, the $16 \mathrm{~S}$ rRNA sequences (MF981847 and MF992084) belonging to M. wenyonii and to 'Candidatus M. haemobos' when submitted to ML analysis were phylogenetically positioned near to other $M$. wenyonii and 'Candidatus M. haemobos' sequences, respectively, detected around the world and supported by high bootstrap values (87 and $100 \%$, respectively) (Fig. 4). 
Fig. 2. Phylogenetic relationships within the Bartonella genus based on the gltA gene. The tree was inferred by using the maximum likelihood (ML) method with the $\mathrm{GTR}+\mathrm{G}+$ I model. The sequences detected in the present study are highlighted in bold. The numbers at the nodes correspond to bootstrap values higher than $50 \%$ accessed with 1000 replicates. Brucella melitensis was used as an outgroup.

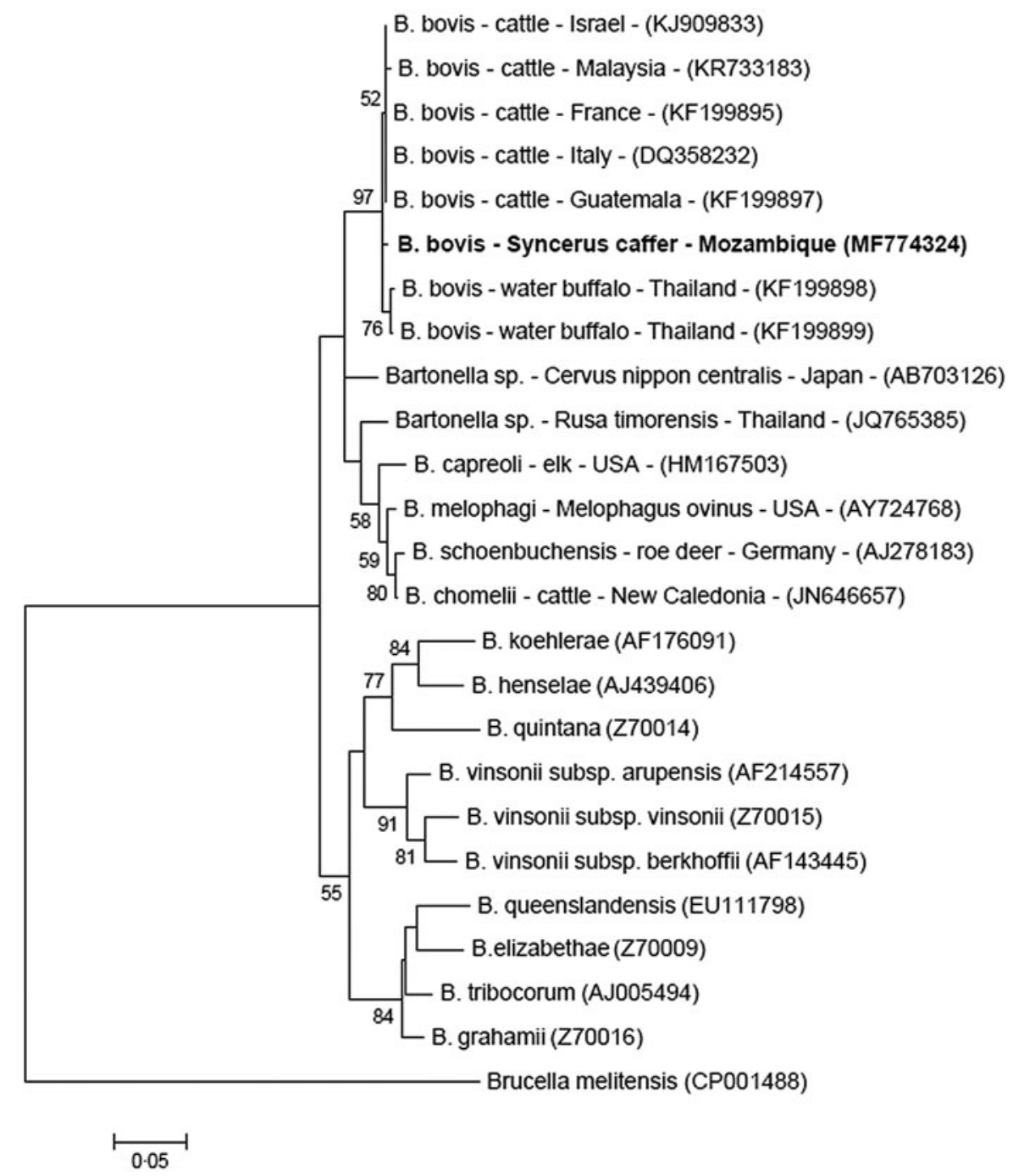

\section{Discussion}

In the present study, the occurrence of Bartonella and haemoplasmas species was assessed in African buffaloes translocated from Marromeu to Gorongosa National Park in Mozambique. Although Bartonella and/or haemoplasmas species have been previously reported in domestic animals (dogs, cats and cattle) (Gundi et al., 2004; Willi et al., 2006; Dahmani et al., 2017), wild animals (rodents, bats and cheetahs) (Kosoy et al., 2010; Kamani et al., 2013; Krengel et al., 2013) and haematophagous arthropods (soft ticks and bat flies) (Billeter et al., 2012; Mediannikov et al., 2014) from African continent, the present work presented, for the first time, the occurrence of these arthropod-bacteria species in $S$. caffer.

Similarly to the occurrence of Bartonella in water buffalo [Bubalus bubalis $(6.8 \%$; 7/103)] from Thailand (Bai et al., 2013), a low occurrence was observed among the animals analysed in the present study $(4.1 \%$; 4/97). Additionally, the prevalence of haemoplasmas reported in the African buffaloes was lower than that previously reported in buffaloes $(32 \% ; 8 / 25)$ from China (Su et al., 2010). However, it is important to highlight that the animals selected in the latter study were showing different clinical signs, such as emaciation, anorexia and decreased milk yields (Su et al., 2010). In addition to animal health status, the difference in the occurrence of Bartonella and haemoplasmas observed in different countries have been attributed to different factors, such as distribution and abundance of arthropod vectors, and environment and landscape features, which could influence the exposure to these agents (Bai et al., 2013).

Syncerus caffer is frequently infested by species of Hyalomma, Rhipicephalus and Amblyomma ticks (Carmichael, 1976; Anderson et al., 2012; Kariuki et al., 2012). These ticks are responsible for transmission of several pathogens frequently reported in African buffalo, such as Theileria spp., Anaplasma spp., Ehrlichia spp. and Babesia spp. (Andrew and Norval, 1989; Eygelaar et al., 2015; Machado et al., 2016). Therefore, it suggests that Bartonella and haemoplasma species detected in $S$. caffer in the present study may be potentially transmitted by these tick species. In addition to possible role of ticks in the transmission of Bartonella, several studies have reported the isolation or molecular detection of Bartonella species in other bloodsucking arthropods associated with wild and domestic ruminants (Chung et al., 2004; Dehio et al., 2004; Halos et al., 2004; Duodu et al., 2013; Gutiérrez et al., 2014). Regarding the haemoplasma transmission, few studies have accessed the mechanisms of transmission by arthropod vectors. Prullage et al. (1993) demonstrated the mechanical transmission of Mycoplasma suis by Stomoxys calcitrans and Aedes aegyptii among susceptible splenectomized pigs. Woods et al. (2005) showed that Ctenocephalides felis is a possible vector of M. haemofelis and 'Candidatus M. haemominutum' among cats. Additionally, bovine-associated Mycoplasma species were molecularly detected in ticks belonging to Dermacentor andersoni (Neimark et al., 2001), Rhipicephalus (Boophilus) 


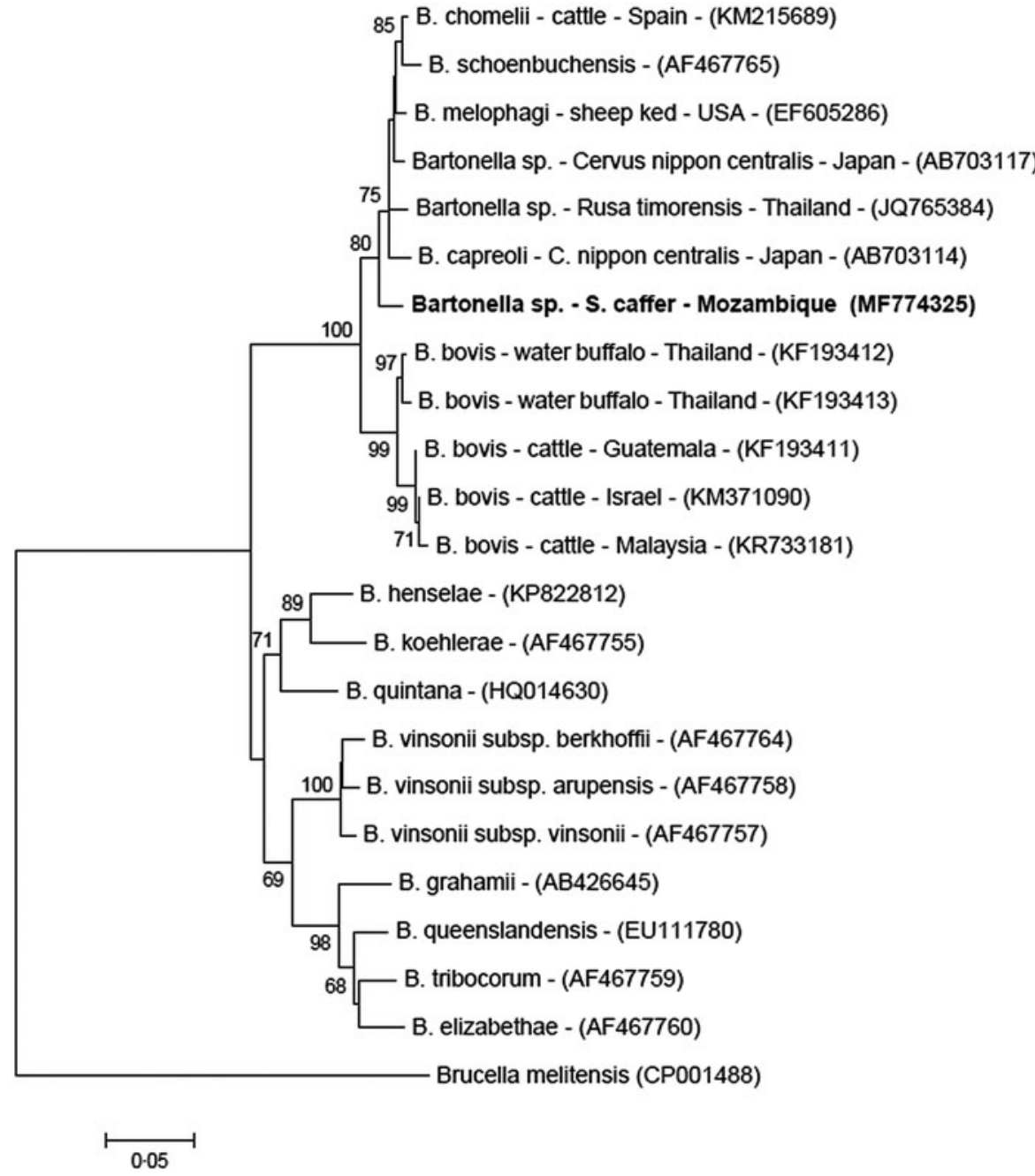

Fig. 3. Phylogenetic relationships within the Bartonella genus based on the $\mathrm{fts} Z$ gene. The tree was inferred by using the maximum likelihood (ML) method with the GTR + G model. The sequences detected in the present study are highlighted in bold. The numbers at the nodes correspond to bootstrap values higher than 50\% accessed with 1000 replicates. Brucella melitensis was used as an outgroup. microplus and Haemaphysalis bispinosa species (Mohd Hasan et al., 2017), among horn (Haematobia irritans), stable (S. calcitrans), horse (Tabanus spp.) (Hornok et al., 2011) and house (Musca domestica) flies, as well as in lice (Haematopinus eurysternus) (Hofmann-Lehmann et al., 2004). These findings suggested that these arthropods may have an active role in the maintenance and transmission of ruminants-associated Bartonella and haemoplasma species. However, experimental studies aiming to analyse the vectorial competence of selected arthropod species are much needed.

In contrast to the phylogenetic analysis (ML) performed with haemoplasmas sequences amplified from $S$. caffer blood samples, which clustered with other $M$. wenyonii and 'Candidatus M. haemobos' sequences detected around the world, the Bartonella gltA and fts $Z$ sequences detected in the same animal (\#62) were positioned in different branches in all different methods analysed (ML, BI and NJ). This uncertainty about the phylogenetic positioning could be explained by two hypotheses. Firstly, there would have been a coinfection with different Bartonella species/genotypes ( $B$. bovis identified by gltA sequence, and a new Bartonella genotype closely related to other ruminant-associated Bartonella identified by ftsZ sequence). Alternatively, the amplified sequences might have represented an infection with a genotype that went through recombinant events. Indeed, the latter phenomena have been already reported in Bartonella species from wild rodents (Harrus et al., 2009; Paziewska et al., 2011), cattle (Gutiérrez et al., 2014) and bats (Bai et al., 2015). These distinct possibilities reinforce the great challenge on Bartonella identification based on direct molecular detection in blood, tissue or ectoparasite samples (Gutiérrez et al., 2014; Kosoy et al., 2017). Although the multiple loci sequencing approach was attempted in the present study for a better understanding of sequences phylogenetic positioning and possible recombinant events and/ or infection by multiple Bartonella species (Kosoy et al., 2017), the unique positive sample (\#62) in CPCR assays was negative in PCR targeting additional genes ( $r p o B$ and groEL), thus precluding to solve this issue. Additional culturing of isolates would have benefited the differentiation of these genotypes/species (Kosoy et al., 2017).

Considering that buffaloes usually do not show clinical signs of tick-borne diseases, a surveillance on this animal species is much needed since they act as carriers for arthropod-borne pathogens to the livestock (Andrew and Norval, 1989; Allsopp et al., 1999; Eygelaar et al., 2015; Van Schalkwyk et al., 2016). Furthermore, since these animals can migrate over large distances, they could spread different pathogens for susceptible wildlife. In the present study, at least three bovine-associated pathogens, namely B. bovis, $M$. wenyonii and 'Candidatus M. haemobos' were reported in $S$. caffer. Regarding the pathogenic potential of the above-mentioned agents, while $B$. bovis have been associated with bovine endocardits (Mailard et al., 2007; Erol et al., 2013), bovine haemoplasmas species have been associated with anaemia, transient fever, decreased milk production, anorexia, weight loss and infertility (Smith et al., 1990; Su et al., 2010; Hoelzle et al., 2011).

In the Marromeu Reserve, the site where animals were caught, buffaloes and cattle used to share the same area. Although little is known about the origin, evolution and dispersion of Bartonella and haemoplasmas species, the low prevalence detected in 


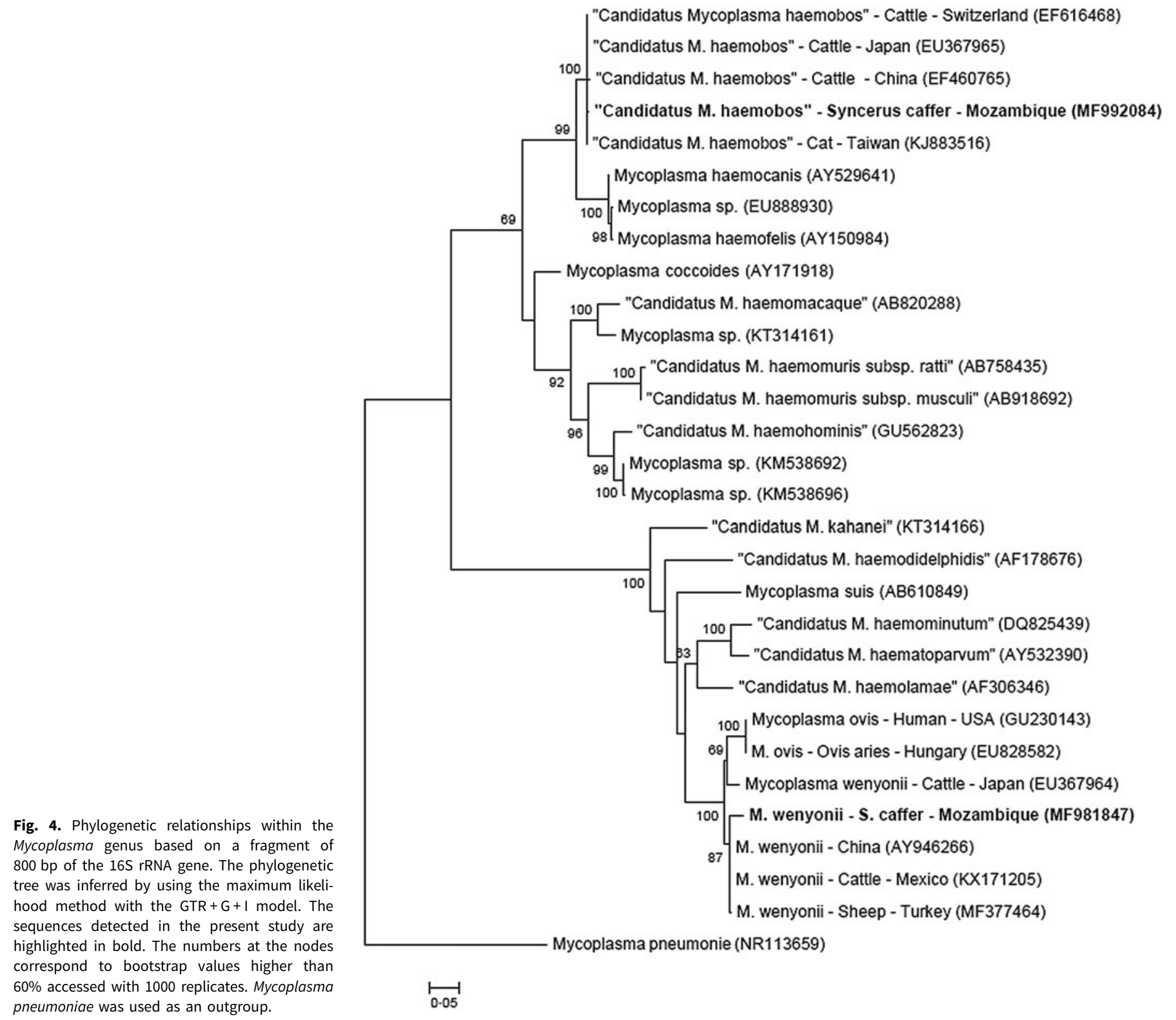

African buffaloes, mainly to Bartonella, coupled to a wide distribution and the constant detection of these bacterial in cattle around the world, suggest that these pathogens may have been transmitted via arthropod-vectors from cattle to buffaloes. On the other hand, there is no contact among cattle and wildlife in Gorongosa National Park, the site where the animals were released. Therefore, the sylvatic animals residing in this area, mainly other ruminant species may be exposed to $B$. bovis, M. wenyonii, 'Candidatus M. haemobos' and Anaplasma spp., as previously reported (Machado et al., 2016). Although it is difficult to assess the impact of these infections in such population, this situation can be catastrophic to immunologically naïve wildlife (Woodford and Rossiter, 1993).

Even though translocation procedures have intended conservation benefits, this attempt may also impose risks to animal health (IUCN/SSC, 2013). During management procedures, it is important to consider that a translocated animal does not represent a single species, but is rather a biological package containing a selection of viruses, bacteria, protozoa, helminths and arthropods. Different reports have showed the complexity of the translocation procedures, either by diseases introduced through the animals or diseases contracted from the resident animals at the release site (reviewed by
Woodford and Rossiter, 1993). Therefore, the veterinary aspects, prior, during and after translocation procedures are extremely important in order to minimize the impact on animal health. Indeed, few studies have been conducted regarding arthropod-borne pathogens in the capture (Marromeu Reserve) and the release (Gorongosa National Park) sites. For instance, Rift Valley fever phlebovirus was detected in buffaloes and cattle sampled in both places between the years of 2013 and 2014 (Moiane et al., 2017). Recently, Trypanosoma vivax and T. vivax-like DNA was amplified in buffaloes and tsetse flies (Glossina spp.) captured in Gorongosa between the years of between 2007 and 2014 (Rodrigues et al., 2017). These findings reinforce the need for further studies in order to better assess the impact of the translocation process on resident fauna.

Although in the present study we were unable to solve the issue regarding the possible occurrence of co-infection or recombination events by distinct Bartonella species, future studies using cloning of amplicons prior to sequencing and the isolation of bartonellae in blood or chocolate agar may help solving this problem, improving the molecular identification and characterization of this important bacterial group in wild ruminants.

In summary, our study showed the molecular occurrence of $B$. bovis, a possible new Bartonella genotypes/species or a genotype 
resulted from recombination events, $M$. wenyonii and 'Candidatus M. haemobos' in African buffaloes submitted to translocation from Marromeu to Gorongosa National Park. Additionally, African buffaloes and other sympatric ruminants living in the release site (Gorongosa National Park) should be evaluated in the future in order to assess the impact of these pathogens in the ecosystem.

\section{Supplementary material}

The supplementary material for this article can be found at https://doi.org/10.1017/pao.2018.10.

Acknowledgments. We are grateful to a number of colleagues, students and local people who helped Dr Carlos Lopes Pereira with the fieldwork for animals capture in the Marromeu Reserve.

\section{Financial support}

This work was supported by grants from the FAPESP (Fundação de Amparo à Pesquisa do Estado de São Paulo - Process number \#2015/ 14896-1) and $\mathrm{CNPq}$ (Conselho Nacional de Desenvolvimento Científico e Tecnológico - Bolsa de Produtividade em Pesquisa Process number 302420/2017-7) delivered to M.R.A. and the Brazilian Agency CNPq within the PROAFRICA to M.M.G.T.

\section{Conflicts of interest}

None.

\section{Ethical standards}

Not applicable.

\section{References}

Allsopp MT, Theron J, Coetzee ML, Dunsterville MT and Allopp BA (1999) The occurrence of Theileria and Cowdria parasites in African buffalos (Syncerus caffer) and their associated Amblyomma hebraeum ticks. The Onderstepoort Journal of Veterinary Research 66, 245-249.

Anderson K, Ezenwa VO and Jolles AE (2012) Tick infestation patterns in free ranging African buffalo (Syncercus caffer): effects of host innate immunity and niche segregation among tick species. International Journal for Parasitology: Parasites and Wildlife 2, 1-9.

André MR, Dumler JS, Herrera HM, Gonçalves LR, de Sousa KC, Scorpio DG, de Santis AC, Domingos IH, de Macedo GC and Machado RZ (2016) Assessment of a quantitative 5' nuclease real-time polymerase chain reaction using the nicotinamide adenine dinucleotide dehydrogenase gamma subunit (nuoG) for Bartonella species in domiciled and stray cats in Brazil. Journal of Feline Medicine and Surgery 18, 783-790.

Andrew HR and Norval RAI (1989) The carrier status of sheep, cattle and African buffalo recovered from heartwater. Veterinary Parasitology 34, 261266.

Bai Y, Malania L, Castillo DA, Moran D, Boonmar S, Chanlun A, Suksawat F, Maruyama S, Knobel D and Kosoy M (2013) Global distribution of Bartonella infections in domestic bovine and characterization of Bartonella bovis strains using multi-locus sequence typing. PLOS ONE 8, e80894.

Bai Y, Hayman DTS, Mckee CD and Kosoy MY (2015) Classification of Bartonella strain associated with straw-colored fruit bats (Eidolon helvun) across Africa using a multi-locus sequence typing platform. PLoS Neglected Tropical Diseases 9, e0003478.

Billeter SA, Hayman DT, Peel AJ, Baker K, Wood JL, Cunningham A, SuuIre R, Dittmar K and Kosoy MY (2012) Bartonella species in bat flies (Diptera: Nycteribiidae) from western Africa. Parasitology 139, 324-329.

Birtles RJ (2005) Bartonellae as elegant hemotropic parasites. Annals of the New York Academy of Sciences 1063, 270-279.

Birtles RJ and Raoult D (1996) Comparison of partial citrate synthase gene ( $g l t A)$ sequences for phylogenetic analysis of Bartonella species. International Journal of Systematic Bacteriology 46, 891-897.
Breitschwerdt EB (2014) Bartonellosis: one health perspectives for an emerging infectious disease. ILAR Journal 55, 46-58.

Breitschwerdt EB (2017) Bartonellosis, one health and all creatures great and small. Veterinary Dermatology 28, 96-e21.

Breitschwerdt EB, Maggi RG, Chomel BB and Lappin MR (2010) Bartonellosis: an emerging infectious disease of zoonotic importance to animals and human beings. Journal of Veterinary Emergency and Critical Care 20, 8-30.

Buffet J-P, Kosoy M and Vayssier-Taussat M (2013) Natural history of Bartonella infecting rodents in light of new knowledge on genomics, diversity and evolution. Future Microbiology 8, 1117-1128.

Carmichael IH (1976) Ticks from the African buffalo (Syncerus caffer) in Ngamiland, Botswana. The Onderstepoort Journal of Veterinary Research 43, 27-29.

Chung CY, Kasten RW, Paff SM, Van Horn BA, Vayssier-Taussat M, Boulouis HJ and Chomel BB (2004) Bartonella spp. DNA associated with biting flies from California. Emerging Infectious Diseases 10, 1311-1313.

Dahmani M, Sambou M, Scandola P, Raoult D, Fenollar $F$ and Mediannikov O (2017) Bartonella bovis and Candidatus Bartonella davousti in cattle from Senegal. Comparative Immunology, Microbiology and Infectious Diseases 50, 63-69.

Dehio C, Sauder U and Hiestand R (2004) Isolation of Bartonella schoenbuchensis from Lipoptena cervi, a blood-sucking arthropod causing deer ked dermatitis. Journal of Clinical Microbiology 42, 5320-5323.

Duodu S, Madslien K, Hjlelm E, Molin Y, Paziewska-Harris A, Harris PD, Colquhoun DJ and Ytrehus B (2013) Bartonella infections in deer keds (Lipoptena cervi) ad moose (Alces alces) in Norway. Applied and Environmental Microbiology 79, 322-327.

Erol E, Jackson C, Bai Y, Sells S, Locke S and Kosoy MErol E, Jackson C, Bai Y, Sells S, Locke S and Kosoy M (2013) Bartonella bovis isolated from a cow with endocarditis. Journal of Veterinary Diagnostic Investigation 25, 288-290.

Ewing B, Hillier L, Wendl MC and Green P (1998) Base-calling of automated sequencer tracer using phred. I. Accuracy assessment. Genome Research $\mathbf{8}$, $175-185$.

Eygelaar D, Jori F, Mokopasetso M, Sibeko KP, Collins NE, Vortser I, Troskie M and Oosthuizen MC (2015) Tick-borne haemoparasites in African buffalo (Syncerus caffer) from two wildlife areas in Northern Botswana. Parasites \& Vectors 8, 1-11.

Godfroid J (2002) Brucellosis in wildlife. Revue Scientifique et Technique (International Office of Epizootics) 21, 277-286.

Gonçalves LR, Favacho ARM, Roque ALR, Mendes NS, Junior OLF, Benevenute JL, Herrera EM, D'Andrea PS, de Lemos ERS, Machado RZ and André MR (2016) Association of Bartonella species with wild and synanthropic rodents in different Brazilian biomes. Applied and Environmental Microbiology 82, 7154-7164.

Gundi AKV, Olivier B, Davous B, Raoult D and La Scola B (2004) Bartonella clarridgeiae and $B$. henselae in dogs, Gabon. Emerging Infectious Diseases 10, 2261-2262.

Gutiérrez R, Cohen L, Morick D, Muncuoglu KY, Harrus S and Gottlieb Y (2014) Identification of different Bartonella species in the cattle tail louse (Haematopinus quadripertusus) and in cattle blood. Applied and Environmental Microbiology 80, 5477-5483.

Hall TA (1999) Bioedit: a user-friendly biological sequence alignment editor and analysis program for Windows 95/98/NT. Nucleic Acids Symposium Series 41, 95-98.

Halos L, Jamal T, Maillard R, Girard B, Guillot J, Chomel B, VayssierTaussat M and Boulouis H-J (2004) Role of Hippoboscidae flies as potential vectors of Bartonella spp. infecting wild and domestic ruminants. Applied and Environmental Microbiology 70, 6302-6305.

Harms A and Dehio C (2012) Intrudes below the Radar: molecular pathogenesis of Bartonella spp. Clinical Microbiology Reviews 25, 42-78.

Harrus A, Bar-Gal GK, Golan A, Elazari-Volcani R, Kosoy MY, Morick D, Aviador B and Baneth G (2009) Isolation and genetic characterization of a Bartonella strain closely related to Bartonella tribocorum and Bartonella elizabethae in Israeli commensal rats. American Journal of Tropical Medicine and Hygiene 81, 55-58.

Hoelzle K, Winkler M, Kramer MM, Wittenbrink MM, Dieckmann SM and Hoelzle LE (2011) Detection of Candidatus Mycoplasma haemobos in cattle with anemia. The Veterinary Journal 187, 408-410.

Hofmann-Lehmann R, Meli ML, Dreher UM, Gönczi E, Deplazes P, Braun U, Engels $M$, Schüpbach J, Jörger $K$, Thoma R, Griot $C$, Stärk KD, Willi B, Schmidt J, Kocan KM and Lutz H (2004) 
Concurrent infections with vector-borne pathogens associated with fatal hemolytic anemia in a cattle herd in Switzerland. Journal of Clinical Microbiology 42, 3775-3780.

Hornok S, Micsutka A, Meli ML, Lutz H and Hofmann-Lehmann R (2011) Molecular investigation of transplacental and vector-borne transmission of bovine hemoplasmas. Veterinary Microbiology 152, 411-414.

IUCN/SSC (2013). Guidelines for Reintroductions and Other Conservation Translocations. Version 1.0. Gland, Switzerland: IUCN Species Survival Commission.

Kamani J, Morick D, Mumcuoglu KY and Harrus S (2013) Prevalence and diversity of Bartonella species in commensal rodents and ectoparasites from Nigeria, West Africa. PLoS Neglected Tropical Diseases 7, e2246.

Kariuki EK, Penzhorn BL and Horak IG (2012) Ticks (Acari: Ixodidae) infesting cattle and African buffalo in the Tsavo conservation area, Kenya. The Onderstepoort Journal of Veterinary Research 79, E1-E4.

Kosoy M, Bay Y, Lynch T, Kuzmin IV, Niezgoda M, Franka R, Agwanda B, Breiman RF and Rupprecht CE (2010) Bartonella spp. in bats, Kenya. Emerging Infectious Diseases 16, 1875-1881.

Kosoy M, David TSH and Kung-Sik C (2012) Bartonella bacteria in the nature: where does population variability end and a species start? Infection, Genetics and Evolution 12, 894-904.

Kosoy M, Mckee C, Albayrak L and Fofanov Y (2017) Genotyping of Bartonella bacteria and their animal hosts: current status and perspectives. Parasitology Special Issue Review, 1-20. doi: 10.1017/S0031182017001263.

Krengel A, Meli ML, Cattori V, Wachter B, Willi B, Thalwitzer S, Melzheimer J, Hofer H, Lutz H, Hofmann-Lehmann R (2013) First evidence of hemoplasma infection in free-ranging Namibian cheetahs (Acinonyx jubatus). Veterinary Microbiology 162, 972-976.

La Scola B, Zeaiter Z, Khamis A and Raoult D (2003) Gene-sequence based criteria for species definition in bacteriology: the Bartonella paradigm. Trends in Microbiology 11, 328-321.

Machado RZ, Teixeira MM, Rodrigues AC, André MR, Gonçalves LR, Barbosa da Silva J and Pereira CL (2016) Molecular diagnosis and genetic diversity of tick-borne Anaplasmataceae agents infecting the African buffalo Syncerus caffer from Marromeu Reserve in Mozambique. Parasites \& Vectors 9, 454. doi: 10.1186/s13071-016-1715-y.

Maggi RG, Compton SM, Trull CL, Mascarelli PE, Mozayeni BR and Breitschwerdt ED (2013a) Infection with hemotropic Mycoplasma species in patients with or without extensive arthropod or animal contact. Journal of Clinical Microbiology 51, 3237-3241.

Maggi RG, Chitwood MC, Kennedy-Stoskopf S and DePerno CS (2013b) Novel hemotropic Mycoplasma species in white-tailed deer (Odocoileus virginianus). Comparative Immunology, Microbiology and Infectious Diseases 36, 607-611.

Mailard R, Petit E, Chomel B, Lacroux C, Schelcher F, Vayssier-Taussat M, Haddad N and Bolouis HJ (2007) Endocarditis in cattle caused by Bartonella bovis. Emerging and Infectious Diseases 13, 1383-1385.

Mediannikov O, Diatta G, Kasongo K and Raoult D (2014) Identification of Bartonella in soft tick species Ornithodoros sonrai in Senegal. Vector Borne and Zoonotic Diseases 14, 26-32.

Michel AL, Bengis RG, Keet DF, Hofmeyr M, Klerk LM, Cross PC, Jolles AE, Cooper D, Whyte IJ, Buss P and Godfroid J (2006) Wildlife tuberculosis in South Africa conservation areas: implication and challenges. Veterinary Microbiology 112, 91-100.

Mohd Hasan LI, Kho KL, Koh FX, Hassan Nizam QN and Tay ST (2017) Molecular evidence of hemoplasmas in Malaysian cattle and ticks. Tropical Biomedicine 34, 668-674.

Moiane B, Mapaco L, Thompson P, Berg M and Albihn A (2017) High seroprevalence of Rift Valley fever phlebovirus in domestic ruminants and African buffaloes in Mozambique shows need for intensified surveillance. Infection Ecology and Epidemiology 7, 1416248.

Neimark H, Johansson KE, Rikihisa Y and Tully JG (2001) Proposal to transfer some members of the genera Haemobartonella and Eperythrozoon to the genus Mycoplasma with descriptions of 'Candidatus Mycoplasma haemofelis', 'Candidatus Mycoplasma haemomuris', 'Candidatus Mycoplasma haemosuis' and 'Candidatus Mycoplasma wenyonii'. International Journal of Systematic and Evolutionary Microbiology 51, 891-899.

Nishizawa I, Sato M, Fujihara M, Sato S and Harasawa R (2010) Differential detection of hemotropic Mycoplasma species in cattle by melting curve analysis of PCR products. The Journal of Veterinary Medical Science 72, 77-79.

Norman AF, Regnery R, Jamenson P, Greene C and Krause DC (1995) Differentiation of Bartonella-like isolates at the species level by PCR restriction fragment length polymorphism in the citrate synthase gene. Journal of Clinical Microbiology 33, 1797-1803.

Paziewska A, Harris PD, Zwolinska L, Bajer A and Sinski E (2011) Recombination within and between species of the alpha proteobacterium Bartonella infecting rodents. Microbial Ecology 61, 134-145.

Prullage JB, Williams RE and Gaafar SM (1993) On the transmissibility of Eperythrozoon suis by Stomoxys calcitrans and Aedes aegypti. Veterinary Parasitology 50, 125-135.

Renesto P, Gouvernet J, Drancourt M, Roux V and Raoult D (2001) Use of $r p o B$ gene analysis for detection and identification of Bartonella species. Journal of Clinical Microbiology 39, 430-437.

Rodrigues CMF, Garcia HA, Rodrigues AC, Costa-Martins AG, Pereira CL, Pereira DL, Bengaly Z, Neves L, Camargo EP, Hamilton PB and Teixeira MMG (2017) New insights from Gorongosa National Park and Niassa National Reserve of Mozambique increasing the genetic diversity of Trypanosoma vivax and Trypanosoma vivax-like in tsetse flies, wild ungulates and livestock from East Africa. Parasites and Vectors 10, 337.

Santis AC, Herrera HM, Sousa KCM, Gonçalves LR, Denardi NC, Domingos IH, Campos JB, Machado RZ and André MR (2014) Molecular detection of hemotrophic mycoplasmas among domiciled and free-roaming cats in Campo Grande, state of Mato Grosso do Sul, Brazil. Revista Brasileira de Parasitologia Veterinária 23, 231-236.

Santos NJR, Brito DRB, Abate HL, Paixão SF, Soares EDS, Vieira TSWJ, Garcia JL, Vieira RFC and Vidotto O (2018) Hemotropic mycoplasmas infection in water buffaloes (Bubalus bubalis) from northeastern Brazil. Comparative Immunology, Microbiology and Infectious Diseases 56, 27-29.

Sato S, Kabeya H, Yamazaki M, Takeno S, Suzuki K, Kobayashi S, Souma K, Masuko T, Chomel BB and Maruyama S (2012) Prevalence and genetic diversity of Bartonella species in sika deer (Cervus Nippon) in Japan. Comparative Immunology, Microbiology and Infectious Diseases 35, 575-581.

Seddon PJ, Griffiths CJ, Soorae PS and Armstrong DP (2014) Reversing defaunation: restoring species in a changing world. Science 345, 406-412.

Soorae PS (2016) Global Re-Introduction Perspectives: 2016. Case-Studies from Around the Globe. Gland, Switzerland: IUCN/SSC Reintroduction Specialist Group and Abu Dhabi, UAE: Environment Agency-Abu Dhabi.

Smith JA, Thrall MA, Smith JL, Salman MD, Ching SV and Collins JK (1990) Eperythrozoon wenyonii infection in dairy cattle. Journal of American Veterinary Medical Association 196, 1244-1250.

Stamatakis A, Hoover P and Rougemont J (2008) A rapid bootstrap algorithm for the RAxML Web servers. Systematic Biology 57, 758-771.

Stoffregen WC, Alt DP, Palmer MV, Olsen SC, Waters WR and Stasko JA (2006) Identification of a haemomycoplasma species in anemic reindeer (Rangifer tarandus). Journal of Wildlife Diseases 42, 248-258.

Su QL, Song HQ, Lin RQ, Yuan ZG, Yang JF, Zhao GH, Huang WY and Zhu XQ (2010) The detection of "Candidatus Mycoplasma haemobos" in cattle and buffalo in China. Tropical Animal Health and Production 42, 18051808 .

Thompson JD, Higgins DG and Gibson TJ (1994) Improving the sensitivity of progressive multiple sequence alignment through sequence weighting, position specific gap penalties and weight matrix choice. Nucleic Acids Research 22, 4673-4680.

Van Schalkwyk OL, Knobel DL, De Clercq EM, De Pus C, Hendrickx G and Van den Bossche P (2016) Description of events where African buffalo (Syncerus caffer) strayed from the endemic foot-and-mouth diseases zone in South Africa 1998-2008. Transboundary and Emerging Diseases 63, 333-347.

Watanabe Y, Fujihara M, Obara H, Matsubara K, Yamauchi K and Harasawa R (2010) Novel hemoplasma species detected in free-ranging sika deer (Cervus nippon). The Journal of Veterinary Medical Science 72, 1527-1530.

Willi B, Tasker S, Boretti FS, Doherr MG, Cattori V, Meli ML, Lobetti RG, Malik R, Reusch CE, Lutz H and Hofmann-Lehmann R (2006) Phylogenetic analysis of "Candidatus Mycoplasma turicensis" isolates from pet cats in the United Kingdom, Australia, and South Africa, with analysis of risk factors for infection. Journal of Clinical Microbiology 44, 4430-4435.

Woodford MH and Rossiter PB (1993) Disease risks associated with wildlife translocation projects. Revue Scientifique et Technique 12, 115-135.

Woods JE, Brewer MM, Hawley JR, Wisnewski N and Lappin MR (2005) Evaluation of experimental transmission of Candidatus Mycoplasma haemominutum and Mycoplasma haemofelis by Ctenocephalides felis to cats. American Journal of Veterinary Research 66, 1008-1012.

Zeaiter Z, Fournier P-E, Ogata H and Raoult D (2002) Phylogenetic classification of Bartonella species by comparing groEL sequences. International Journal of Systematic Evolutionary and Microbiology 52, 165-171. 